G

COUNTERFUTURES

Left thought \& practice Aotearoa 


\title{
Transforming Our Future in te Moana Nui a Kiwa
}

\author{
Interview with Kassie Hartendorp
}

\begin{abstract}
N MID-2016 Sue Bradford interviewed young Te Whanganuia-Tara (Wellington) activist Kassie Hartendorp for Counterfutures. Kassie is passionately engaged in a range of work with other young people in the LGBTQI+, Māori and Pasifika communities, and offers interesting perspectives on contemporary radical left politics in our country and our region.
\end{abstract}




\section{Sue Bradford}

Kia ora Kassie - thank you very much for doing this interview. Could you give the people reading this some idea about your whakapapa, background and history?

\section{Kassie Hartendorp}

I come from a range of different family streams because I was an adopted child. On my biological side my father is from Italy, Scotland and England and my mother is from Ngāti Raukawa ki te Tonga. On my adopted side my mother is from England and my father from Holland. My whakapapa and my family are quite broad because of those different streams, but I honour them all in what I do. I was born in Te Whanganui-a-Tara, and spent my first six years of life in Upper Hutt, then moved to Whanganui and lived there for twelve years. As soon as I could - at age 18-I left Whanganui and moved back to Wellington. I've been down here for eight years now.

In terms of my political whakapapa, I first got into research and ideas around feminism and sexism. When I ended up going to university in Wellington I met a whole bunch of socialists and spent some time in socialist groups. I consider that my political whakapapa, because that's the space where I learnt political ideas - a specifically socialist or communist setting. It's only in the past few years that I've really been connecting with other streams of my whakapapa too in terms of my Māoritanga, particularly as an adopted child who was not told they were Māori. Decolonisation has been a big part of my kaupapa, but it's also a really personal thing that's had a huge impact on my politics. 
SB

Can you talk a bit about the work you're doing at the moment?

$\mathrm{KH}$

The main paid mahi I've been doing for the past three years has been as a youth worker in an inner city youth service, where I do case management, mentoring, run groups, and so on. I'm also quite involved with the LGBTQI+ community. I'm part of a takatāpui community group, Tīwhanawhana, which has a political kaupapa as well. I'm in Kava Club, which is a group of Māori and Pacific creatives who I look at the interconnection of art and politics. I'm also involved with BOX Oceania, a group of indigenous and people of colour. We say that we 'live, love, beyond and above the rainbow'. Our work together is particularly concerned with the intersection of sexuality, gender, racism and indigeneity. I enjoy that, it's a space where we're able to talk about queer or trans politics from an indigenous perspective, so that's really fulfilling. I'm also a supporting member of Fightback, a socialist organisation. I recently edited a youth issue of Fightback that came out in July. I'm also thinking about ways of doing collective activism within our local community - but these are just conversations at present.

SB

Was there any time or aspect of your life that triggered you to become radical Left in all the different ways you are?

$\mathrm{KH}$

I think anybody who does the work we do right now has prob- 
ably felt a sense of injustice for most of their lives. I can't think of any one particular formative moment, but putting words to things around sexism was always really important for me. Another thing that got me going was the myth surrounding capitalism - the idea that if you just work hard enough you can succeed and live this idyllic, capitalist dream. I knew that my parents worked extremely hard, often at minimum wage jobs, and I never really saw them get ahead. To me this was a contradiction. As a teenager I thought that if these hardworking people weren't able to succeed in this world that they're meant to succeed in, then something else needs to be investigated. I wanted to understand what was really happening and to ask what alternatives there were. When I went to university I started finding other words, names and frameworks for the feelings I was having about society and I was able to develop a systemic analysis.

\section{SB}

What were the theories or ideology that particularly captured you at the beginning?

\section{$\mathrm{KH}$}

I got captivated by Gender and Women's Studies, especially theories around patriarchy and capitalism. I just knew something was wrong in the world and I wanted to do something about it. The socialists happened to be people who were actively doing something. I didn't want to just sit around and think about things, I wanted to be on the ground making change. I was originally with the Workers Party, which then kind of split into Fightback. I've just picked up pieces from different theories and different ideas along the way, and I don't subscribe wholly to any one particular thing. However, socialist, communist and Marxist analyses of 
capitalism have, to this day, remained really important to me although I've also found them lacking in some respects.

For instance, I think Marxism - and other academic work - offers a lot theoretically, but doesn't always offer much in terms of practice within a community context in Aotearoa. So the theory is cool: you want to form a revolutionary party and support a revolution, that's all good and fine. But how do you actually put that into practice? In the Pākehā Left I've seen quite a lot of behaviour that alienates people who would otherwise be interested in the radical transformation of society.

When I started investigating and learning more from a Te Ao Māori framework I gained ideas about what practice could actually look like - because here I'm deeply invested in the collective. Ultimately I have a problem with ways of organising that begin and end with the individual. Indigenous ways of existing are based on the idea of the collective. I'm interested in identifying the stepping points for getting from the current context to one where we're working collectively and fighting against oppression and exploitation. I feel like many spaces on the Pākehā Left don't cover that middle ground. The higher-up analysis is there, and the explanatory frameworks are really great, but the practices on the ground don't always assist in creatively building towards that goal. I've been thinking about that gap for a while, but now I'm coming at it by organising within a Māori and Pacific framework - one that is based on whakapapa, whanaungatanga and manaakitanga. It is a practical framework for me to start collective work with others in.

\section{SB}

Have you been in a rōpū that's ngā iwi tātou katoa where you've tried to bring those principles of things like manaakitanga and whanaungatanga into the organisation consciously? 


\section{$\mathrm{KH}$}

I have experience working in Pākehā spaces that have no grasp of those principles, and I've been in Māori and Pacific spaces that understand these in such depth that there's nothing conscious about it because it's so natural. What I don't have is an experience where these two spaces have come together, and I think realising that is an essential thing. To me, as a person who is both Pākehā and Māori, I assume those two things can coexist. Recently I asked a kaumātua I look up to about a project I had in mind that was seeking to incorporate values from Te Ao Māori but would also involve tauiwi. He said: 'Actually, Pākehā need to find their own models and you will encounter a cultural clash at some point because those two things are not the same'.

This comes back to the very crux of the contradiction around what it means to be living on indigenous land that is dominated by the structures of the coloniser, and to have both Pākehā and Māori wanting to change or destroy these structures. Is it the responsibility of Pākehā to be trying to transform those structures that have come from a Pākehā, western point of view? Or do Māori need to organise separately to fight these structures from their own perspective? Most people will say you need both things at the same time. As a mixed race person I embody that contradiction. So where I'm at right now - where I'm finding my feet and my politics - is very exciting and challenging.

\section{SB}

Is there anything you'd like to share about socialist organisations currently? 


\section{$\mathrm{KH}$}

The thing that I've really loved about learning from socialist groups is having strong analysis and research, and then tying that to the reality of our work. The emphasis on the collective is key, and that's been affirmed and supported by my work within socialist organisations. Some of the difficulties within these same organisations concern understandings of the current context and the relevance of Marxism or socialist analysis for the $21^{\text {st }}$ century. What that can boil down to is sitting around reading books written over a hundred years ago about a very historically specific space in time. A lot of the Marxist left has not caught up with the current context. I'm not meaning any disrespect to people who have been my comrades, but let's be real. To give an example, selling the organisation's paper on the street is still considered by some an ideal action for a Marxist or socialist activist. That approach came out of a particular context; what is the equivalent of that context today? It's probably not selling a physical paper in a world that doesn't carry change! It's an example of holding onto something that is seen as a tenet of ideology when in fact it was a tactic of an ideology. Tactics need to be flexible. They need to be relevant to the current moment. We need to realistically consider what we bring with us, what we change, and what we leave behind.

The white domination of socialism in Aotearoa is also something that I have had to really grapple with. It's not that socialist politics and politics around indigeneity are not compatible, but the way they are practised, and sometimes the roots from which they have come, can really get in the way. When I see groups that are quite orthodox I feel there's a lot missing in terms of what being indigenous is about, and what that means in political theory and practice. 


\section{SB}

You've been a supporter of our radical Left think tank project Economic and Social Research Aotearoa (ESRA) since the beginning - can you say a little about why?

\section{$\mathrm{KH}$}

I think the Left needs a political, intellectual armoury to be able to begin to find the tools and the weapons to counter the Right. For me it's just that simple. I'm overwhelmed by the number of years - decades, centuries! - that the Right has been able to formulate ideas - to plan, think, strategize - in ways that are unrivalled in terms of what the Left has been able to do. So to me ESRA is a place where some of those intellectual, radical ideas can begin to come together and take form, and to be of use to people who are on the ground or in the academy.

I think the challenge will be how ESRA engages around Mātauranga Māori and Pacific knowledges. A lot of awesome work has been done across the country, and the question is how ESRA will orientate itself towards that work. Most of the Leftists I know working around politics in an academic manner come from a really western paradigm - one that usually imports European ideas and philosophers, and which maybe sees indigenous ideas as slightly lesser.

I recently had an awesome weekend in Palmerston North celebrating the $45^{\text {th }}$ anniversary of the Polynesian Panthers; I think that the knowledge in that room from former Polynesian Panthers - and also people who were involved with the Springbok tour protests, and other movements from that time - was awesome. I'm also particularly excited about a lot of the work being done by people around the West Papua campaigns. We need to continue thinking about the Pacific as a region, and what Aotearoa's place in that region can and should be. 
SB

Over the last couple of years I've been part of a lot of discussions about the need to build a new political organisation, or organisations, on the radical Left. Would you support such an effort and like to be part of such discussions?

\section{$\mathrm{KH}$}

I think a lot about this stuff. It's a massive question, and an exciting one. Ultimately I think we need to be building political power outside of places like Parliament - because that's not a legitimate power, it's not truly democratic. So then the question becomes: where are the places where that other political power can be built? I think posing this question creates an opportunity for people from different radical Left streams to come together. It would be a challenge due to the fragmentation of the Left - and also because this fragmentation exists throughout society as a result of neoliberalisation.

Some of my most recent experiences have been in political environments that are very individualistic in nature and don't have much by way of a common cause or framework, with people not working together in good faith. To be quite honest about it, this has happened in spaces of feminist politics and queer politics. It's exhausted me and I've felt a need for a different framing for where to go. I've found forms of white feminism to be quite empty - and there are times I have been complicit in this myself. For instance, I've had experiences where people seemed more interested in being seen to have the 'right politics' and for saying the 'right thing,' rather than necessarily having integrity and doing the right thing. I've been involved in these kinds of micro-focussed pseudo-political communities a fair amount and sometimes, when you're in these spaces, it's quite hard to envision organising beyond that. 
I think there is a possibility for different radical Left strands to come together - this is something that absolutely needs to happen - but things like not having strong unions in the way we once did is an issue here. Creating a new organisation would take a radical rethinking of our current political context. Oh no, I probably sound really pessimistic!

\section{SB}

Do you have hope despite some of the things you've just said?

\section{$\mathrm{KH}$}

I have hope because I have faith in people, and in the possibilities for resistance and change, and that we can find a different way of being together that allows for true freedom and liberation. I firmly believe that if any place in the world can do, then it is Aotearoa. There are many ways that we are in a position to make radical political change. Our colonising systems run deep, but are not as entrenched as in many other parts of the world. The main thing that gives me hope at the moment is the indigenous basis for organisation and change. I see this as a framework that offers different ways of relating to one another and the environment, than takes place in mainstream Pākehā society. It's an approach that can allow us to be in it for the long haul.

I think dealing well with relationships is missing from a lot of 'identity politics.' I should make it clear that I don't use that concept in a derogative way, I use it to mean a politics that is linked to concepts of individual identity. Politics on this level can be really difficult - for instance, for me to identify as takatāpui places me within a whakapapa of a whole bunch of activists, a whole bunch of whānau, a whole bunch of ancestors, so it's never just me alone. The politics of identity can burst open a world of 
nuance and connection to our historical and current conditions. But when we reduce it to the lowest common denominator, which is protecting and defining your own individual identity, then I find it hard to imagine a positive political programme based just on that.

The thing I love about queer spaces is that people I have known to be radical within these communities are often the embodiment of what a transformed society could be. They are not afraid to push the boundaries around how they live and exist in the world. To me that's inspiring. An openness to different ways of being transformative is an important part of what the Left needs to encompass. We can't rely on old forms and tactics to get us through. I've been to so many activist meetings where we just have the same old conversations and reach the same old conclusions. What I've learned from engaging with the queer community is how to creatively push our political thinking out and be willing to look for new ways of addressing old problems.

SB

Is there anything you'd like to say in conclusion?

\section{$\mathrm{KH}$}

At this point I'm thinking there needs to be more of a discussion about what tino rangatiratanga looks like in practice, and how we can get there. What will such a project look like moving forward from here? Many of these conversations are already taking place, particularly around constitutional reform. What I am most interested in is being a part of, and supporting, tangata whenua and tangata o te moana to be able to organise, dream, imagine, create - and to be involved in thinking about what a transformative Te Moana Nui a Kiwa or Pacific region looks like. I feel this 
has been missing from a lot of Pākehā Left spaces that I've been a part of. We share this vast ocean, this sea of islands, as the late Epeli Hau'ofa wisely wrote, and we have to think about what that means politically. What would our tupuna have thought about our current system? How do we honour their stories, and those of our grandchildren?

Lastly, I'd like to thank all of those who have shared their thoughts, dreams and actions with me along this journey. I am grateful for every ounce of courage and inspiration that I am blessed to witness every day, both here and afar. I'm hopeful we will create new ways of existing together. 
If you like what you have read, please subscribe or donate.

\author{
G \\ COUNTERF UTURES \\ Left thought \& practice Aotearoa \\ (C) Copyright Counterfutures 2016
}

